Prefinal version, published in: Kasia M. Jaszczolt, Ken Turner (eds.): Meaning Through Language Contrast. Vol. 2, Amsterdam/Philadelphia, Benjamins, 2003, 345-371. EISBN 978-90-272-9677-1

\title{
A question of Time? - Question types and speech act shifts from a historical-contrastive perspective.
}

\author{
Some examples from Old Spanish and Middle English
}

Verena Jung, University of Leeds, UK

Angela Schrott, Ruhr-University, Bochum, Germany

\section{Introduction}

Our paper on question types and speech act shifts has a twofold aim. Firstly, we want to combine the perspective of contrastive pragmatics with a historical dimension in order to analyse the speech act of asking a question and speech act shifts from a cross-linguistic historical perspective. The premise is that speech acts change and that speech acts described in texts are therefore understood differently at different times. Secondly, in order to document illocutionary changes and shifts we make use of translation studies and determine possible changes via a comparison between the original text and its translations.

Our study has the following structure. After introducing the concept of historical pragmatics and discussing some crossroads between historical and contrastive pragmatics (1) we link both disciplines with the field of translation studies (2). Based on this theoretical framework we demonstrate the relevance of historical pragmatics for translation practice by looking at two examples of historical texts - one from Old Spanish and one from Middle English - and their various modern translations. In the Old Spanish Cantar de mio Cid (3) we focus on question types and ask whether the medieval text presents question types which are not asked any longer. In our second text, Chaucer's Wife of Bath's Prologue and Tale (4), we analyse two examples of speech act shift portrayed in the various translations of this historical text and discuss possible motivations for the illocutionary shift in two of the translations given.

\section{Contrastive pragmatics and historical pragmatics: Crossroads in the field of pragmatics}

\subsection{Historical pragmatics}

As the title of our paper suggests, we want to introduce a historical dimension into the contrastive study of verbal interaction. Before we turn to the interrelations of contrastive and historical pragmatics we want to sketch our understanding of historical pragmatics.

As pragmatics is concerned with the study of language use as social interaction it is a genuinely historical discipline in the sense that it always considers the socio-historical situation in which the interaction takes place (Cherubim 1980: 4, 6f., 7-9, 19). This historical dimension of the pragmatic approach becomes particularly clear when we study verbal interactions in speaker communities of the past. It is this branch of pragmatics that focuses on speaker interactions in the past that is usually referred to by the notion of historical pragmatics (Jucker \& Jacobs 1995: 4-5). The central aim of historical pragmatics is to describe verbal interactions as historically determined ways of interacting and to study linguistic means and their use across different historical stages of a language (Jucker \& Jacobs 1995: 4-6, 11-14, 19-21; Fritz 1995: 469, 
1997: 47f.). As a subdiscipline of historical pragmatics, historical dialogue analysis considers dialogues as social behaviour regulated by language structures and historical contexts of acting and communicating (Cherubim 1980: 7-9). Historical dialogue analysis interprets dialogue forms as tools for solving communicative tasks and describes the ways in which elements of dialogue interaction are subject to historical changes. ${ }^{1}$ Very prominent elements of dialogue interaction are of course speech acts and speech act sequences. Recent studies in historical dialogue analysis (cf. the articles in Jucker, Fritz \& Lebsanft 1999) show that changes affect dialogues in many ways: changes include not only maxims of interaction and politeness rules (Ehlich 1992) but also speech act patterns and speech acts themselves. In the perspective of historical pragmatics speech acts are seen as historically determined types of verbal interaction whose realisation is influenced by a number of social parameters and cultural traditions (Schlieben-Lange \& Weydt 1979: 66-67; Schlieben-Lange 1983: 13; Arnovick 2000: 2, 39, 142f.). Changes can concern the speech act itself, the rules for its performance and the illocutionary patterns in which it is embedded. As types of verbal interaction speech acts are texts, and as texts they can form traditions of their own which are handed down from one speaker-generation to the next. If we consider speech acts as texts that have their own traditions, it follows that speech acts like asking a question or making a complaint do not belong to the history of a specific language but to the history of a cultural community that uses this speech act as a communicative tool (Coseriu in Schlieben-Lange \& Weydt 1979: 74-76, 77). Speech acts therefore cannot simply be linked to the history of a language but are part of the cultural history of a specific community. These cultural traditions have to be taken into consideration when we want to understand dialogue interactions in medieval texts and render them adequately when translating. Cultural traditions can concern politeness rules and patterns of interaction as well as the roles a cultural community attributes e.g. to men and women. In most cases, changes in speech acts and dialogue patterns are not limited to the linguistic level but go hand in hand with changes in the realia of the extra-linguistic world (Lebsanft 1999: 270f., 284f.).

\subsection{Historical and contrastive pragmatics}

After this brief sketch of some implications of historical pragmatics, we now turn to the question of how historical pragmatics is related to contrastive pragmatics.

The common ground of both disciplines has been pointed out by various studies in historical pragmatics (e.g. Jucker \& Jacobs 1995: 3f.). Both disciplines compare the realisation of components of interaction in different cultures - be it cultures that follow each other on the time line or cultures that exist at the same time in different environments. Like historical pragmatics, contrastive pragmatics understands verbal interaction as social behaviour shaped by cultural and sociohistorical parameters and focuses on the differences and the variety of elements and patterns of interaction. Contrastive pragmatics aims at describing and explaining the variety of interactional styles found in different cultures and wants to interrelate the performance of speech acts with the cultural and sociohistorical parameters that may affect their performance (Blum-Kulka \& House 1989: 5). Here, differences in the performance of speech acts lie not only in the linguistic expressions but also in a different system of cultural values (Wierzbicka 1991: 25ff., 40, 44, 50ff., 59f., 61). There are not only institutionalised speech acts like baptizing that are culture-bound but all speech acts are culture specific (Wierzbicka 1991: 149f., 156). Therefore, we should not ask how members of different cultures perform e.g. apologies but how they behave e.g. in a situation when they have done wrong to a person and want to remedy the situation. Thus, both disciplines are concerned with the

\footnotetext{
${ }^{1}$ For a discussion on the historicity of dialogues see Fritz 1995:469, 470f. and 1997:47f.
} 
realisation of elements of verbal interaction in different languages and cultures and both disciplines concentrate on comparing the ways in which a specific speech act is realised in different communicative and cultural contexts (Jucker \& Jacobs 1995: 3f.; Jucker \& Taavitsainen 2000: 68). But let us go back to the interrelationship of both disciplines. How 'contrastive' is historical pragmatics and how 'historical' is contrastive pragmatics? The contrastive nature of historical pragmatics becomes evident in the blueprint for the domain of historical dialogue analysis given by Fritz (1995: 469-470, 1997: 47f.). Fritz distinguishes three phases of historical dialogue analysis: the interpretation of individual texts, the contrastive study of historical texts and, finally, the systematic analysis of the evolution of dialogue forms. Yet the study of a medieval text is in itself already contrastive as we implicitly compare the text to the texts of our own discourse universe and use our own communicative experience to understand the text. This contrastive view is always inherent in historical pragmatics, even if we concentrate on a single medieval text (Fritz 1995: 469; Lebsanft 1999: 269f.). However, whereas historical pragmatics always offers a contrastive perspective, contrastive pragmatics does not necessarily embrace a historical dimension: contrastive pragmatics compares a certain speech act in different speaker communities in a synchronic cross-section and does not aim at sketching the diachronic evolution of the speech act (Jucker \& Taavitsainen 2000: 68). Nevertheless, contrastive pragmatics may have a diachronic dimension, e.g. when we realise that a speech act is differently performed in a specific speaker community and we want to know the historical reason for these differences (cf. Stein 1985).

The conceptual affinity implies that both disciplines have to face similar problems concerning the variability and historicity of speech acts. In order to describe the verbal realisations of a speech act, both disciplines take this speech act as an invariable tertium comparationis (Jucker \& Taavitsainen 2000: 69) for the description of differences in speech act performance, be it synchronically or diachronically. Recently, linguists in historical pragmatics as well as in contrastive pragmatics have become aware of the fact that we cannot presuppose the invariability of a certain speech act. Not every culture has the same set of speech acts. A speech act like apologizing does not necessarily have an identical function in different cultures: the difference may not only concern the verbal realisation but also the function speakers assign to a certain action (Wolfson 1989: 179). Another problem both disciplines share is whether changes merely concern the linguistic representation of a speech act or whether the speech act itself changes (Lebsanft 1999: 270f., 284f.) - a vital distinction which we will have to consider in our comparison of the medieval texts with their modern translations.

\section{Translation studies and pragmatics}

After giving an outline of the relations between contrastive pragmatics and historical pragmatics, we want to introduce the ways in which both fields and our text analysis are to be linked with translation studies. Before we take a closer look at the historical perspective, some remarks on the relationship between translation theory and pragmatics in general.

While linguistics has come to be seen as an important tool both in the description of the two languages a translator deals with and in the description of the translation process (Catford 1965; Albrecht 1973; Diller \& Kornelius 1978), the newer disciplines of linguistics such as pragmatics have entered translation studies much more slowly. Studies in contrastive linguistics tended to be more descriptions of the linguistic system than of language in action (Hawkins 1986) and translation methodology books also tended to concentrate more on the system side than on pragmatic considerations. While text typology and the influential skopos theory (Reiss 1982; Reiss \& Vermeer 1984: 214) became increasingly a factor seen as determining different 
translation strategies for different text types, the level of translational strategy of the individual sentence was interpreted to be the semantic rather than the pragmatic level of the individual phrase. However, in the so-called functionalist approach, represented by Hönig and Kussmaul (1982), Wilss (1982, 1996) and Nord (1997), pragmatics becomes relevant not only in terms of the determination of the text-type but also for the translation of the individual element. Hönig and Kussmaul have integrated speech act theory into translation theory and teaching methodology in depth and explain the relevance of seeing utterances as speech acts in their 1982 didactic handbook on translation. Kussmaul (1980) also has translated and edited some of the major writings on speech act theory.

The functionalist approach postulates that the illocution itself remains unchanged, but this often means a rather substantial change concerning the choice of linguistic means. Illocutionary invariance often implies that syntactic structures and sentence types cannot remain unchanged and have to undergo variance. As shown by House (1997: 82f.) German and English differences in formulating apologies or offers prove that the linguistic realisation of the basic forms of speech acts can vary considerably from one speaker community to the other. Thus, the polite offer "Why don't you take your coat off?" of an English host might be interpreted as an almost philosophical or personal question by a German guest, and might not produce the expected "Thank you" and a handing over of the coat but rather a reaction like "Well, I usually wear my coat indoors" or "Why do you want to know?". The German structural equivalent "Warum ziehst du deinen (ziehen Sie Ihren) Mantel nicht aus?" - as this English phrase is often rendered in translations of American or English TV series - creates a different and very strange effect in the German version. Wierzbicka (1991: 212) analyses this form as a "whimperative construction" that should be taught as such to learners of the English language (1991: 212, 216, 218) ${ }^{2}$.

Because of the disastrous consequences of ignoring the pragmatic level some translation methodologists and practitioners, such as Hönig and Kussmaul (1982) and also functionalist Christiane Nord (1997) advocate a top-bottom process of translation, i.e. the pragmatic level must be seen as the first level from which all other translation decisions must be derived. Thus, the identification of the speech act would precede vocabulary questions and decisions. Like Hönig and Kussmaul (1982), Christiane Nord (1997) gives pragmatics top priority in the process of translation:

In functional translation, problems should therefore be dealt with in a top-down way. This means that a functional translation process should start on the pragmatic level by deciding on the intended function of the translation (documentary vs. instrumental). A distinction is then made between those functional elements of the source text that will have to be reproduced "as such" and the ones that must be adapted to the addressee's background knowledge, expectations and communicative needs [...] (1997: 68)

In a recent article, Hönig (1995) develops the idea that conference interpreters need to be aware of the speech act intended by the speaker in order to be able to translate the illocution correctly. In his article he analyses examples of political criticism formulated as questions in Prime Minister's Question Time at the House of Commons. Thus, when the opposition party in a discussion on police action against domestic violence asks the question "Why is it that with a problem of such importance and when so many women throughout the country are at risk no action has been taken since January?" the illocution is not that the

${ }^{2}$ Wierzbicka (1991:212) gives the following paraphrase for this conversational routine: Why don't you do X?

a. I say: I want you to say, if you can, why you/we shouldn't do X.

b. I think you can't (say why).

c. I think it will be a good thing if you/we do it.

d. I say this because I would want you to do it. 
opposition party is asking to be supplied with information. The interrogative structure here functions as a rhetorical question with assertive value and expresses the conviction that there is no valuable reason for not taking action against that dangerous situation. As a consequence, the German rendering of the interpreter, whether in question form or not, must render this as a critical statement and not as a mere thirst for more information, otherwise the communicative intention has not been rendered despite achieving "invariance on the content level”.(Reiss 1982: 20)

The functional approach also demands that the translator bears in mind the text function as a whole, i.e. the text type and the traditions that mark the text. This can best be explained by using Reiss' and Vermeer's (1984) text typology to describe how it influences the translator's decision. Reiss and Vermeer postulate that advertising texts, being examples of operative texts (Reiss \& Vermeer 1984: 214), demand extreme faithfulness on the message level, i.e. what is the aim of the text, but are not particularly concerned with rendering invariance on the semantic content level, while literary texts and technical texts tend to demand more invariance on the semantic level. When dealing with literary texts, the translator has to consider especially the poetic traditions that mark the text on a formal and functional level.

Now let us return from those more general remarks on the pragmatic perspective in translation to our idea of using translation studies in the field of historical pragmatics. One link is already hinted at by Jucker and Jacobs (1995). Among the branches of historical pragmatics Jucker and Jacobs (1995: 11) count the approach of "pragmaphilology". Pragmaphilology describes the contextual aspects of historical texts, the conditions of their production and reception. If we want to know how historical texts were received through time, translations are important witnesses for the reception of a text and the way it was understood or misunderstood. The way literary texts like the Cantar de mio Cid and the Wife of Bath's Prologue and Tale have been received through time can be described via an inventory of their translations. In our paper, however, we do not embrace a complex pragmaphilological approach that would seek to write the history of a literary text reflected in its translations. Although our translations were chosen in order to compare different 'styles' of translation we cannot pretend to give a well-balanced and representative choice of translation styles or schools of translation. The primary concern of our paper is not how the translation generally reflects or modifies the literary text but how it renders certain types of illocutions we find described in the medieval text. To some extent, our approach could be called pragmaphilological on a speech act level in the sense that we study the way certain speech acts are received and rendered in the translations.

Translation comparison is one of the most frequent exercises used in translation studies. It can be used for various purposes, didactic - distinguishing between different types of translation - or as a quality assessment exercise. In order to be used as a quality assessment, criteria must first be established and it must be explained in what way they are relevant to the making of a good translation (House 1997: 9ff.). But any translation comparison, whether for prescriptive or descriptive purposes, should concentrate on predefined elements in order to be conclusive (Frank 1988), just as any linguistic study would. In this study, the speech act level will be the level of comparison.

For our analyses we have chosen an Old Spanish text, the Cantar de mio Cid from the 12th century and a Middle English text from the 15th century, the Wife of Bath's Prologue and Tale from Chaucer's Canterbury Tales. The temporal distance implies that the texts are deeply marked by what Jauß (1977: 1016) called the 'alterity' of the medieval text - a strangeness of the text that demands special efforts of understanding on the part of the reader. This strangeness characterises the text not only on the level of literary aesthetics but also on the level of the interactions we find depicted in the text: those interactions are mimetic representations of the way people acted or were supposed to act many centuries ago (Cerquiglini 1981: 247). As speech acts and patterns of interaction are exposed to historical changes, it is possible that a 
reader or translator is confronted with an illocutionary type or pattern that is no longer part of his culture. Here, the modern reader or translator has to reconstruct the illocution, making use of a hermeneutic circle and referring to the historical background as well as to the literary traditions of the text.

When translators have grasped the pragmatic profiles of the interactions they render them with the linguistic means of modern English, Spanish or German. Thus, the linguistic transfer follows the cultural transfer. The translator takes the pragmatic function as a starting point and looks for the linguistic means which are apt to render the illocution. In order to achieve this aim, the translator often not only uses different linguistic means but may also add explanatory passages to the text and remodel the pragmatic structure of the text. A pragmatic remodelling of a text is given when the semantic and syntactic modifications in the translated text imply a change of the pragmatic pattern in the original. The translator can e.g. change the sequence of speech acts, insert an additional speech act or render a certain speech act with a speech act type that does not exactly correspond to the original. We can think of different reasons for such a change in the pragmatic pattern: it may be due to a simple misunderstanding of the medieval text or it may result from the specific strategies chosen by the translator. However, in the perspective of the historicity of speech acts highlighted by historical pragmatics, a third possibility comes up. If we keep in mind the variability of illocutions over time, a pragmatic remodelling can also indicate that the speech act or speech act sequence described in the medieval text no longer exist in the translator's culture (Wierzbicka 1991). In that case, a faithful rendering of the pragmatic pattern could easily cause misunderstandings or produce a speech act sequence whose meaning the modern reader cannot grasp. Therefore, in order to keep intact the basic communicative value of a string of interactions, the translator has to remodel the pragmatic pattern more or less profoundly - the illocutionary shift then reflects a pragmatic evolution and enables the linguist to trace diachronic changes in the speech act set. In that perspective, pragmatic remodellings are possible indicators that illocutions or illocutionary sequences have undergone changes. Based on these assumptions, contemporary translations of historical texts can make good material for tracking down evolutions in diachronic pragmatics.

The description of what the translator needs to do in order to render a passage in such a way that the communicative needs of the addressee are met corresponds in some way to the task of historical pragmatics when trying to determine if a speech act has changed either in form or content from one period to the other. This shows that using the knowledge of historical pragmatics may be an essential tool to top-down translation methodology for a translator of medieval texts. We will see this illustrated in the text examples from the Cantar de mio Cid.

\section{Questions not asked any longer? Question types in the Cantar de mio Cid and their translations}

\subsection{The act of asking a question}

If dialogues and speech acts have a historical dimension we have to consider the possibility that an elementary illocution like the act of asking a question can also be exposed to changes over time - a strong possibility as we analyse interrogative acts described in a text of the late 12th century. On the functional level processes of change can affect questions in two ways. Firstly, the pragmatic profile of a specific type of question like "Where are you, my brave vassal?" can change. Secondly, the way a question is performed in certain dialogue contexts can change, i.e. the conversational presentation of the interrogative act as well as its embedding in the illocutionary context can undergo variance. In order to describe the specific functions of the questions in the Old Spanish text and their translations we have to define the pragmatic function of 
the act of asking a question. Against the background of this definition we can characterise the function in the text and describe possible shifts in pragmatic meaning. ${ }^{3}$

Questions are marked by a missing propositional parameter in the set of information represented in the utterance. In $w h$-questions of the type "Where did the brave vassal go?" the lacking information is marked by the interrogative adverb; in yes/no-questions like "Did the brave vassal go to Castile?" the proposition is complete but the truth value of the proposition as a whole is not assured. The speaker's knowledge about a relevant situation is fragmentary and the speaker lays open a knowledge deficit in need for specification. ${ }^{4}$ However, the knowledge deficit exposed by the question does not always function as a request to the interlocutor to deliver the lacking information - the speaker can present the deficit without expecting the addressee to fill the gap. Therefore, questions do not automatically function as requests for information. ${ }^{5}$ But even if a question is not aimed at eliciting information, the evocation of an information deficit has a highly activating potential: by pointing at the knowledge gap, the speaker can call upon the addressee to fill the gap (Liedtke 1998: 165-167; Bucher 1994: 242). The highly activating power of questions to call up responses manifests itself in the fact that questions are often bound to the pattern of the adjacency pair of question and answer where the question as first element draws the answer after it. ${ }^{6}$ The wide definition given here is to be understood as a prototype for the act of asking questions (Schrott 1999: 338; cf. also Arnovick 2000: 16) - a definition that is wide enough to embrace not only typical but also 'untypical' question acts like the ones we will find in the Old Spanish text.

As examples for the question types used in the Cantar we have deliberately chosen two types of whquestions which are clearly marked by their syntactic structure as interrogative sentences in Old Spanish. This makes sure that in all the examples we analyse, the translators were confronted with an utterance that is syntactically marked as an interrogative structure in the Old Spanish original. If the translator chooses to render this structure with an illocution other than a question, we can be sure that this modification cannot be due to a syntactic ambiguity of the Old Spanish sentence structure - the translator's decision must be motivated differently.

\subsection{Some remarks on the text and its translations}

As a textual basis for this analysis we refer to the Cantar de mio Cid, an Old Spanish epic poem or cantar de gesta, probably written at the end of the 12 th century. ${ }^{7}$ With a medieval text like the Cantar de mio Cid the historical understanding of the literary genre is especially important. ${ }^{8}$ The relationship between the Cid and his vassals e.g. can only be understood on the background of the feudal system in general and of the

\footnotetext{
${ }^{3}$ For a more explicit discussion of the speech act of asking a question see also Schrott 1999 and 2000.

${ }^{4}$ Cf. for example Schlieben-Lange 1983:96; Kerbrat-Orecchioni 1991:18.

${ }^{5}$ Cf. Searle's definition of the question as a special type of directive, Searle 1969:66, 69 and 1979:44-47, 48-51. For more literature on questions see Schrott 1999 and 2000.

${ }^{6}$ On the question-answer sequence as an adjacency pair see Sacks, Schegloff, \& Jefferson 1974:711, 716f., 728; Kerbrat-Orecchioni 1991:9; Bucher 1994:239.

7 The period of Old Spanish extends from the 12th to the 15th century, for a closer look on the periodisation of the Spanish language see Eberenz 1991.

${ }^{8} \mathrm{Cf}$. the concept of "alterity" that characterises medieval texts according to Jauß 1977:10, 13-14.
} 
Cid's sacrosanct authority in particular. It is also important that the Cantar as an early vernacular text spreads from an oral tradition and is influenced by a performance culture (Walsh 1990: 1).

The chosen translations cannot pretend to represent the spectrum of translations that have been made of the Cantar de mio Cid nor do we intend to depict the reception of the medieval text via its translations. ${ }^{9}$ The translations represent different 'styles' of translation but as we have not been able to screen all translations of the Cantar into modern English or Spanish the versions presented constitute in a certain way a 'random sample'. ${ }^{10}$ For our comparison we have chosen two translations into modern Spanish and two translations into modern English. In the case of the Spanish versions, we have intralingual translations from Old Spanish (castellano medieval), a period that ends around 1450 (Eberenz 1991), into modern Spanish whose beginnings are located around 1650. Here, the Spanish translations can also be seen as 'modernisations' of the text that remain within the diachronic evolution of the Spanish language.

As we pointed out already, our translation comparison focuses on the rendering of speech acts and on the pragmatic remodelling of illocutions. For historical pragmatics as a discipline that wants to trace changes in the speech act culture, it is crucial to be able to decide whether a remodelled pattern may reflect a change or whether the modification is conditioned by translational strategies. Therefore, it is very helpful to throw a glance at the guidelines and aims the translators evoke in their prefaces.

As translations into modern Spanish we have chosen the well-known translation by the poet and essayist Pedro Salinas, written in 1926, and a more recent translation by Francisco Marcos Marín (1997). With his translation Salinas. ${ }^{11}$ wants to tear down the linguistic barriers that prevent the modern Spanish reader to know and love the Cantar de mio Cid - Salinas does not write for specialists but for a reader who is generally interested in literature without special historical or literary knowledge (Salinas 1926: 10). ${ }^{12}$ With his verse translation, Salinas means to preserve the poetic qualities of the text and recreate the first masterpiece of Spanish poetry for a modern public (Salinas 1926: 11). The translation shall fill the text with life, communicate the "fuerte virtud poetica y humana" of the Cantar and win the epic poem the hearts of today's audience (Salinas 1926: 11-12). For the translation, Salinas points out the following guidelines: the translation is supposed to be clear and absolutely faithful to the medieval text ("fiel y claro"). He wants to translate "punto por punto" and consequently retains e.g. the repetitions in which the text abounds. ${ }^{13}$ Salinas wants to recreate the Cantar in a modern version that is a poetic text of its own - the translator seems to take the part of a modern juglar or singer of tales and act as a mediator between the medieval text and modern readers. This 'autonomy' of the translation as a poetic recreation becomes also apparent in the first edition of the translation (1926) where we find only the translation and no reprint of the Old Spanish text is given.

\footnotetext{
${ }^{9}$ For translations as receptions of medieval texts see also Grosse 1986; for information on the international reception of the story of the Cid see Rodiek 1990.

${ }^{10}$ López Estrada gives an overview of translations into modern Spanish (1961:LXIV- LXV).

${ }^{11}$ Salinas also wrote several essays on the Cantar (Salinas 1961).

${ }^{12}$ Salinas 1926:10: "la antigüedad del lenguaje tiene confinada esta obra de arte en un círculo de lectores forzosamente reducido."

${ }^{13}$ Salinas 1926:11: "Fidelidad absoluta al texto del poema, sin desviaciones en busca de ornato, sin amplificaciones ni desarrollos casi nunca."
} 
Like Salinas, Francisco Marcos Marín points out that the maxim of his translation is faithfulness to the text. Marcos Marín's version modernises the text so that a modern reader with a certain culture can understand most of it. ${ }^{14}$ However, this modernisation is limited by Marcos Marín's maxim to work out a translation that is as close as possible to the original in order to respect what he calls the "coherence of the text'. ${ }^{15}$ Marcos Marin's verse translation follows this guideline even at the cost of keeping some expressions that may have an archaic character for the modern reader. The faithfulness to the original implies that the translation carefully preserves the formulaic style of the Cantar (1997: 108f.). Marcos Marín modernises the text only when the 'faithful' translation could lead to a misunderstanding of the text (1997: 110). In a way, the translation is a part of the text edition like the foot notes in which Marcos Marín comments the Old Spanish text. The translation is fully integrated in the edition and is not meant to be a poetic recreation of the text. ${ }^{16}$

As English translations we have chosen two quite recent translations of the Cantar, one by Peter Such and John Hodgkinson (1987), and the other one by Rita Hamilton and Janet Perry (1975). Similar to Salinas and Marcos Marín, Peter Such and John Hodgkinson (1987) want to give a translation that is faithful to the text and keeps its poetic style. Such and Hodgkinson favour a "literal rendering of the text" and it is their aim "to preserve details of form as far as to do so would produce an acceptable English reading" (1987: 35). In their English version they intend to "reproduce something of the style and flavour of the original" as far as possible in modern English - the translators are in general reluctant to depart from the text and modify the text only "in order that our translation should work as a convincing English version" (1987: 35). By following these guidelines they hope to retain the spirit of the text as well as the "formality of idiom" that characterises the poetic work. ${ }^{17}$

Different guidelines are advocated by Rita Hamilton and Janet Perry in their prose translation (1975). In contrast to Such and Hodgkinson, they are not primarily concerned with the maxim of faithfulness to the text but highlight that they intend to give a translation whose style is more "current" for today's readers than the epic style of the original text (1975: VII). The main aim of Hamilton and Perry is to support the modern reader with a text that presents "current English usage". To achieve this, they abandon the formulae of the Old Spanish text and sometimes suppress the repetitions of the epic poem. Their translation which is meant to be read independently from the original does not aim at retaining the poetic character of the text but wants to adapt it to the communicative experiences of the modern reader.

The translation comparison will show in what respects the guidelines may have influenced the way the Old Spanish text is modelled on the pragmatic level.

\footnotetext{
${ }^{14}$ Marcos Marín 1997:108: "Actualizamos el texto del Cantar de manera que sea inmediatamente comprensible para un lector moderno, con un cierto grado de cultura, dentro de algunes límites."

${ }^{15}$ Marcos Marín 1997:108: "Para mantener una coherencia textual hemos procurado que nuestro texto no se apartase mucho del original, aunque ello implicase mantener alguna expresión más arcaizante, [...]."

${ }^{16}$ On the techniques with which the translation was elaborated see Marcos Marín 1997:110-111.

${ }^{17}$ Here Such and Hodgkinson (1987:35) quote a passage that Tobias Smollett includes in the preface of his translation of Don Quijote (1755): "He has endeavoured to retain the spirit and ideas, without servilely adhering to the literal expression of the original; from which, however, he has not so far deviated, as to destroy that formality of idiom, so peculiar to the Spaniards, and so essential to the character of the work."
} 


\subsection{A special use of the where-question}

When working on the question types in the Cantar, the linguist realises that some uses of questions or other speech act types do not seem to cause any problems of understanding even for a modern reader without special knowledge of this text tradition: the every-day communicative experience of the modern reader is sufficient to understand the speech act. Those illocution types are used more or less in the same way we use them today and their pragmatic functions have remained unchanged. However, we find other question types whose use puzzles even the medievalist. It is those puzzling uses that indicate that the performance of a speech act type may have changed. Here, problems of understanding arise which can be reflected in the translations of the text and shifts in pragmatic meaning may indicate that the interaction represented in the text had to be rendered differently because it no longer forms a part of the modern reader's communicative experiences.

Our first example is such a 'puzzling' question type, a special use of the where-question. In the Cantar de mio Cid, we find several very similar situations where the Cid, surrounded by his most faithful liegemen, calls upon one vassal to perform a mission. He begins his briefing by asking a where-question (V.26182623; Ed. Montaner, English translation by Such and Hodgkinson):

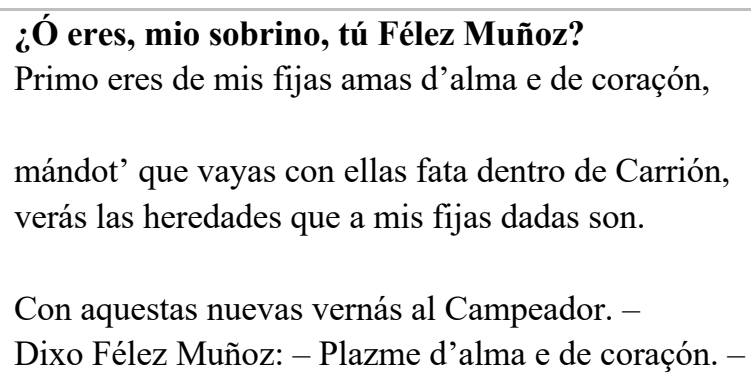

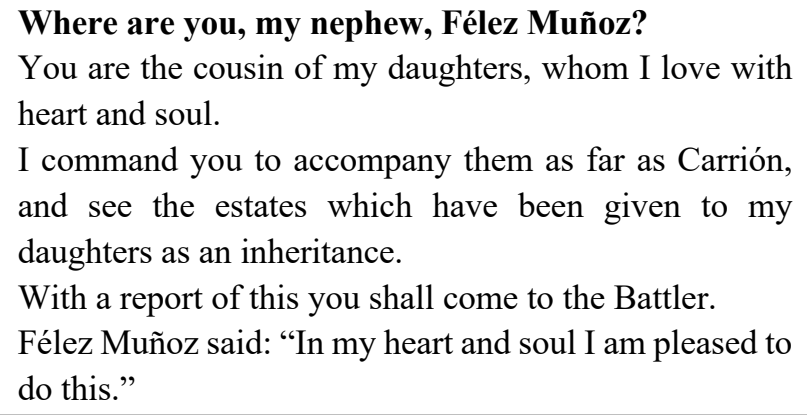

As the vassal is present before the Cid's eyes, the question is obviously not supposed to elicit information about the whereabouts of the vassal. By asking the question the Cid does not want to know where the vassal is, he wants to know whether the vassal is there for him, prepared to perform his orders. Here, the wherequestion belongs to a ritualised strategy which expresses the ideal of a well-functioning feudal system.

In the Cantar we find four similar scenes in which the where-question is used to focus on one candidate and serves as preliminary to a command - the interrogative structure functions as question act but it fulfils a purpose no longer familiar to the modern reader. For our translation comparison, two leading questions arise. Firstly, we have to ask whether the translation preserves the communicative value the speech act or speech act sequence has in the Old Spanish text. Secondly, influenced by the approach of historical pragmatics, we want to find out to which extent the translation retains the cultural characteristics of the interaction sequence, i.e. to what extent a possible alterity and strangeness of the interaction are still present in the translation. 


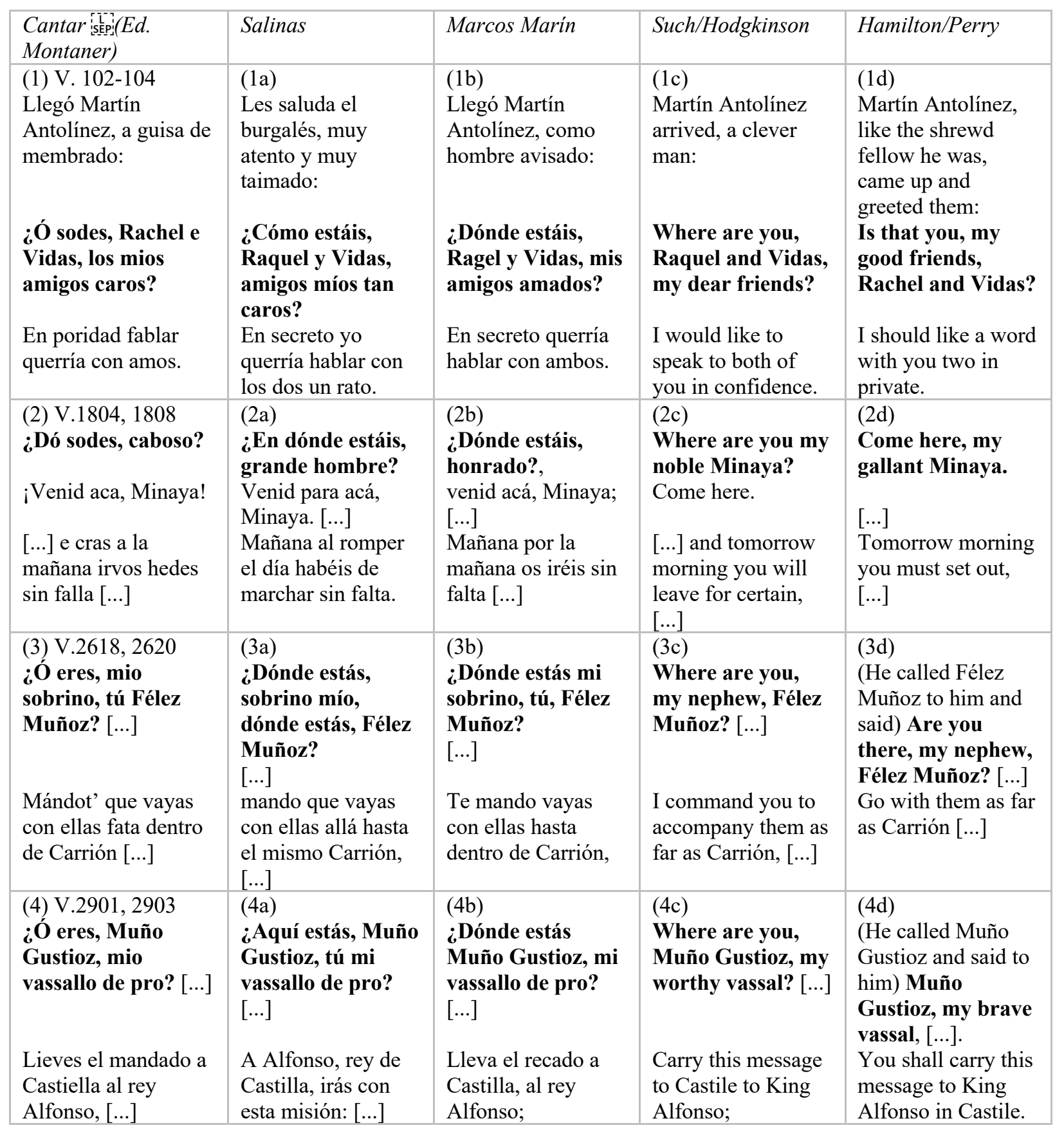

As to the translation of the interrogative structure, the versions form two groups. Marcos Marín and Such and Hodgkinson keep the interrogative structure of the where-question and preserve the question act as such. On the level of the speech act sequence, they do not modify the illocutionary pattern of the Cantar.

A different choice has been made in the translations by Salinas and Hamilton and Perry. Whereas Hamilton and Perry never translate with a where-question, Salinas keeps the type of the where-question in example (2a) and (3a) where he even repeats the interrogative structure. The repetition in (3a) introduces a touch of impatience as if the Cid was already waiting for the vassal to come and fulfil his orders: "Where are you, where are you? I want you to leave for Carrión." Although this modification slightly changes the 
pragmatic value it is still very close to the original and it can remind the reader of a pattern he is familiar with. In the examples (1a) and (4a) Salinas does not keep the where-question. In (1a) the changes are rather complex. Firstly, Salinas changes the context of the illocution. Whereas the original only mentions the arrival of the clever Martín Antolínez, Salinas inserts a passage that qualifies the following enunciation as a greeting. What is more, he changes the where-question into the question ¿Cómo estáis? ("How are you?") which is clearly marked as a greeting formula. Here, the pragmatic pattern undergoes a deeper modification than in (3a). However, in spite of the modification, the basic illocutionary value is preserved as the greeting formula picks out the addressee, focuses on him and functions as a preliminary to what the speaker has to say. ${ }^{18}$ The modification Salinas chooses in (4a) has the same effect. Here, Salinas replaces the wherequestion with a yes/no-question that has only weak interrogative power. The speaker knows that the addressee is there and asks only for confirmation or some other signal of co-operation. A corresponding translation is also chosen by Hamilton and Perry in example (3d). Like in the greeting example, Salinas here (4a) succeeds in keeping intact the communicative value of the pattern.

In the translation by Hamilton and Perry we find similar techniques. Like Salinas, Hamilton and Perry insert a short narrative passage that presents the question as a greeting (1d). However, they do not go so far as to replace the where-question by a genuine greeting like "How are you?" but opt for a yes/no-question as if the speaker was not sure about the addressee's identity. As questions like "Is that you, my good friends...?" are frequently used for establishing contact with the addressee, the translation can render the focusing effect the where-question has in the original. We find a similar effect in (3d) where the yes/no-question functions analogously to Salinas' version (4a). In two examples, Hamilton and Perry suppress the question act as a whole. In (2d) where the original presents a sequence of question and imperative they suppress the question, keep only the imperative and underline the element of command. In (4d) the vassal is simply addressed with his name before the briefing starts. In this example, and likewise in (3d), the translators feel obliged to insert a short stage direction in brackets in order to illustrate the communicative situation. The stage instructions are slightly ambiguous: they imply that the addressee has to be called before the Cid whereas the original makes clear that the vassals are present before the Cid's eyes. Whereas Hamilton and Perry retain the communicative value of the pragmatic pattern in examples (1d) and (3d), this can be doubted for their versions (2d) and (4d) in which they suppress the question. In (4d) the stage direction and the address of the vassal still render in some way the idea of a focusing speech act that prepares the briefing; in (2d) however, this pattern is not given any longer and is replaced by a simple order to the liegeman.

The translations compared illustrate two different strategies on the pragmatic level. That each strategy is represented by a Spanish and an English translation points to the fact that the different translational styles are not due to the different language systems. Marcos Marín's intralingual version and Such and Hodgkinson's interlingual translation retain the pragmatic pattern of the original. As this pattern is not familiar to the reader, he may easily understand Where are you, my nephew, Félez Muñoz? (3c) as a question asking for the whereabouts of the knight - in that case, keeping the sentence type would produce a different speech act. As we showed in our discussion of this verse, a philological interpretation is necessary to reconstruct the pragmatic profile: in modern Spanish as well as in modern English the illocutionary pattern retains the strangeness and alterity that characterises the interaction sequence in the Old Spanish text. The translation is careful not to touch the aesthetic signifiant of the text and produces a transparent translation behind which the original text in its alterity is still visible - in a way the translation functions as a 'paraphrase' of the original speech act sequence. The difficulty for the reader does not lie in the Old Spanish

${ }^{18}$ For a study on linguistic structures and functions of greetings see Lebsanft 1988. 
question type $¿ O$ O eres...? whose pragmatic potential overlaps with where-questions in modern Spanish and English. What has changed is the part the question plays in the illocutionary sequence whose function is closely linked to the feudal system. Thus, modern readers find themselves confronted with a pragmatic pattern whose meaning they may find difficult to grasp - they are in the same position as the medievalist who seeks to reconstruct the interaction in the Old Spanish text. In contrast to the 'paraphrasing' translations that leave part of the cultural transfer to the reader, Salinas' Spanish version and Hamilton and Perry's English translation remodel the pragmatic pattern in order to create a speech act sequence that belongs to the cultural repertoire of the reader while keeping intact the original's communicative values. As we have seen, this attempt to find functional equivalences in today's culture is successful in most cases. However, what is lost to a certain extent, is the alterity of the interactional culture we find in the Cantar de mio Cid.

\subsection{Rhetorical questions}

The second example we want to discuss is concerned with the use of rhetorical questions. We define rhetorical questions as a special use of interrogative sentences where the interrogative structure serves to perform an assertion (Meibauer 1986: 76). Thus, rhetorical questions can be seen as indirect assertions (Meibauer 1986: 32-42; Schrott 2000: 270-271) that can be inferred from the interrogative structure. As a rhetorical device, rhetorical questions are neither bound to a specific language nor to specific linguistic structures - whether a question is rhetorical or not depends on the context. In the Cantar we find four passages where the fictional narrator uses rhetorical questions in a very specific way. We limit the analysis to one rhetorical question of that type and compare the way it is rendered in the modern translations. ${ }^{19}$

\begin{tabular}{|c|c|c|c|c|}
\hline $\begin{array}{l}\text { Cantar } \\
\text { Montaner })\end{array}$ & Salinas & Marcos Marín & Such/Hodgkinson & Hamilton/Perry \\
\hline $\begin{array}{l}\text { V.1214, } 1218 \\
\text { el oro e la plata, } \\
\text { ¿quién vos lo podrié } \\
\text { contar? } \\
{[\ldots]} \\
\text { e los otros averes } \\
\text { ¿quién los podrié } \\
\text { contar? }\end{array}$ & $\begin{array}{l}\text { (a) } \\
\text { y el oro y plata } \\
\text { ganados ¿quién } \\
\text { los podría } \\
\text { contar? [...] } \\
\text { y además le tocan } \\
\text { bienes que no se } \\
\text { pueden contar. }\end{array}$ & $\begin{array}{l}\text { (b) } \\
\text { el oro y la plata } \\
\text { ¿quién os lo } \\
\text { podría contar? } \\
{[\ldots]} \\
\text { y las otras } \\
\text { ganancias ¿quién } \\
\text { las podría } \\
\text { contar? }\end{array}$ & $\begin{array}{l}\text { (c) } \\
\text { and who could } \\
\text { reckon the value } \\
\text { of the silver and } \\
\text { the gold they } \\
\text { seized? [...] } \\
\text { who could } \\
\text { reckon the value } \\
\text { of the other goods } \\
\text { he gained? }\end{array}$ & $\begin{array}{l}\text { (d) } \\
{[\ldots] \text { there were }} \\
\text { untold qualities of } \\
\text { gold and silver } \\
{[\ldots]} \\
\text { the value of the rest } \\
\text { in kind was beyond } \\
\text { reckoning. }\end{array}$ \\
\hline
\end{tabular}

In the example given the interrogative structure "Who could count the gold and silver?" implies the assertion that nobody is able to count those riches and evokes a notion of infiniteness (Meibauer 1986: 132). With this rhetorical question the fictional narrator highlights that the riches are so enormous that they surpass the imagination of the audience as well as his own imagination. Whereas Marcos Marín and Such and Hodgkinson in both examples keep the rhetorical question, Salinas drops the second rhetorical question and paraphrases the concept of infiniteness ("he got riches that cannot be counted"). In Hamilton and Perry's version no trace of the rhetorical device is left - they replace both rhetorical questions by paraphrases that

\footnotetext{
${ }^{19}$ Rhetorical questions of the type discussed here are also to be found in the following passages of the Cantar: V. 698700; V. 1966-1971. For a more thorough analysis of this question type see Schrott 2000:273-276.
} 
keep the idea of infiniteness on the content level. ${ }^{20}$ However, in the Cantar the idea of infiniteness is not simply stated, with the rhetorical questions the fictional narrator addresses the audience - an interaction that functions as a fictional recreation of the interaction between the singer of tales, the juglar, and his audience. The translation by Hamilton and Perry fades out the figure of the narrator and effaces those artfully elaborated traces of oral performance. The pragmatic pattern of the original is not only remodelled but simply left out so that the aesthetic signifiant of the text and its alterity undergo a profound change. Thinking of the communicative experiences of the modern reader who is well-acquainted with rhetorical questions it is in our opinion a modification that does not seem necessary in order to adapt the text to today's communicative culture.

\section{Translation comparison and historical pragmatics: An example of speech act shifts in Chaucer translations}

4.1 Understanding Chaucer - shifted focus in the speech acts portrayed in the various translations - statement of status versus lament

As in the translations of the Cantar, the following analysis of shifted focus in Chaucer's Wife of Bath's Prologue and Tale highlights the question of consistency of the communicative value of the original, therefore, the first step is to look at the original and determine the type of illocution contained in one text passage from the original, the historically determined text. We will then look at the translations, in this case, two so-called intralingual translations, translations into modern English, and two into modern German and attempt to determine their illocutionary value.

As the first two translations are in fact translations into a more modern stage of the same language, they are particularly interesting in terms of historical pragmatics, as the language system will not be responsible for most of the necessary adaptations. Therefore, a change in either form or function of the speech act is likely to be the reason for a translational decision. As has been shown in the case of the wherequestions in the Cantar, keeping a particular sentence type can cause a pragmatic shift in the understanding of the modern reader. This phenomenon was demonstrated even more clearly by the example of "Why don't you take your coat off?" and its German non-equivalent "Warum ziehst du deinen (ziehen Sie Ihren) Mantel nicht aus?" - here, keeping a particular surface structure creates a different speech act in the new community.

Only after differences in speech acts have been analysed does the question of motivation for these shifts come into play. For the translation practitioner, determining which version is closer to the original communicative purpose is crucial - for the purpose of historical pragmatics this question is also relevant, but it is only one aspect in the tracing of changes in speech acts through the passage in time. However, for a shift in emphasis to be exclusively determined by historical change, it would have to be used by several or all translators of one passage. If the shift occurs only in some versions but not in others, this suggests rather that a different translational strategy was used by the different translators. This can be seen in the following example from Chaucer:

\footnotetext{
${ }^{20}$ If we look at all four examples in the Cantar, we see that Hamilton and Perry always suppress the rhetorical question whereas Salinas in general keeps all the rhetorical questions and only leaves out the one in the example we quote.
} 


\begin{tabular}{|l|l|l|l|l|}
\hline $\begin{array}{l}\text { Chaucer Text } \\
\text { (Riverside Ed.) }\end{array}$ & Coghill & Lumiansky & Kemmert \\
\hline $\begin{array}{l}\text { III, 1-3 } \\
\text { Experience, though } \\
\text { non auctoritee/ were } \\
\text { in this world, is right } \\
\text { ynogh for me/ to } \\
\text { speke of wo that is in } \\
\text { marriage. }\end{array}$ & $\begin{array}{l}\text { If there were no } \\
\text { authority on earth/ } \\
\text { Except experience, } \\
\text { mine, for what it's } \\
\text { worth, and that's } \\
\text { enough, for me, all } \\
\text { goes to show/ } \\
\text { That marriage is a } \\
\text { misery and a woe. }\end{array}$ & $\begin{array}{l}\text { My experience } \\
\text { gives me } \\
\text { sufficient right to } \\
\text { speak of the } \\
\text { trouble there is in } \\
\text { marriage, even if } \\
\text { there were no } \\
\text { other authority in } \\
\text { the world. }\end{array}$ & $\begin{array}{l}\text { Erfahrung ist für } \\
\text { mich, selbst dann, } \\
\text { wenn es keine } \\
\text { Autoritäten auf } \\
\text { dieser Welt gäbe, } \\
\text { völig ausreichend, } \\
\text { um über das Leid } \\
\text { im Ehestand } \\
\text { sprechen zu } \\
\text { können. }\end{array}$ & $\begin{array}{l}\text { Erfahrung kann } \\
\text { hinlänglich mich } \\
\text { belehren, wenn } \\
\text { nicht dafür } \\
\text { Autoritäten wären, } \\
\text { Wie doch der } \\
\text { Ehestand is voller } \\
\text { Leid. }\end{array}$ \\
\hline
\end{tabular}

In this famous example, the very beginning of the Wife of Bath's Prologue to her tale, all five versions, the original, the intralingual and the interlingual translations have the form of a statement. On the surface, the differences between each of the two versions in the same language are syntactic in nature. However, in view of a top-down process, the syntactic restructuring would of course only be a consequence of a perceived communicative function for which a restructuring may or may not be necessary in order to create the same function, depending on the closeness of the two speaker communities.

The sentence focus of the original and of the versions by Lumiansky and Kemmler is on experience, whereas the focus of Coghill and Lehnert is on woe. In more traditional linguistics, this might have been seen as a stylistic difference. But changing the focus of a sentence has implications for the speech act it contains. If the focus of the sentence is experience, then the illocution of the passage would be to state authority, to claim a certain status. If the focus of the sentence is woe in marriage, then the passage is a lament. Both are appealing to the listener, but in the one case for respect and attention and in the other version more for pity. That the versions of Lumiansky and Kemmler are closer to the speech act pattern of the original is our interpretation, as there are slight differences in focusing elements between English and German and there could have been different focus rules in Middle English.

The question of motivation for the shift in speech act from the original in Coghill's and Lehnert's versions can have several interpretations. One would be to suggest that the copying of the syntactic structure of the original was expected to automatically create the same illocution (which is not the case, due to differences in focus structure between the two languages, cf. Doherty 1990: 282; Jung 2002: $140 \mathrm{ff}$.), the other would be that the modern reader or two of the modern readers did interpret the speech act differently due to a change of cultural interactional patterns. One reason for this could be a different perception of a woman's role in the world, the idea that the interpretation of the speech act as 'lament' would fit better into the cultural picture of this time or the perceived traditional view of the historic time in which the text was written.

Kussmaul (1995: 32f.) cites an interesting example of motivation for what is clearly a translation mistake, very clearly even a misreading of a text, but a misreading which, in his view, is supported or even created by a shift in thought patterns and attitudes of a society. In this case, the time lapse between the text and the translation is not, as in our case here, more than 500 years, but only 40 years. In a passage from the book Male and Female written by anthropologist Margaret Mead in 1949 
[...] both men and women share the same images of what makes a marriageable or an unmarriageable woman, a good husband, a fascinating lover whom any woman would be a fool to marry, or a born old bachelor [...] (Margaret Mead. 1962 [1949]. Male and Female. Penguin Books, Harmondworth, p. 271)

the sentence a fascinating lover whom any woman would be a fool to marry was translated in the sense of "whom any woman would be a fool not to marry" by a surprising number of students. While overlooking a negation or putting one in is not uncommon in translators, especially untrained ones, the fact that this happened to so many students with this particular sentence was seen by Kussmaul as an indication that general beliefs act as semantic frames when interpreting a text. This would explain the fact that most women in 1990 immediately assumed that a good lover must make good husband material and therefore inserted a not here. Thus, changes in our verbal interaction expectations might make us misunderstand historical texts for that reason more than or as much as problems with meaning changes of certain vocabulary or changes in the rules of syntax structure.

Therefore, one possible interpretation for the different versions of this passage could be that the two translators who have a different illocution to the one in the Chaucer text came to that interpretation not only through failure to recognise syntactic differences between German and Middle English or Modern English and Middle English, but also, because the lamenting Wife of Bath fitted better into their general image of medieval women than the self-assertive version. This is of course not a claim that could be maintained on one passage alone, the fact is simply, that the portrait created by means of the verbal portrayal of this Wife of Bath, in Coghill and Lehnert, clearly differs from that of Lumiansky and Kemmler.

\subsection{Different contextualisation and explicitness create different assumptions: Self-reproach versus boast}

\begin{tabular}{l|l|l|l|l|}
\hline $\begin{array}{l}\text { Chaucer Text } \\
\text { (Riverside Ed.) }\end{array}$ & Coghill & Lumiansky & Kemmler & Lehnert \\
\hline $\begin{array}{l}\text { III, 149-151 } \\
\text { In wyfhod I wol use } \\
\text { myn instrument/ As } \\
\text { frely a my Makere } \\
\text { hath it sent./ } \\
\begin{array}{l}\text { If I be dangerous, } \\
\text { God give me sorwe. }\end{array}\end{array}$ & $\begin{array}{l}\text { If I turn difficult, } \\
\text { God give me } \\
\text { sorrow. }\end{array}$ & $\begin{array}{l}\text { If I am } \\
\text { standoffish, may } \\
\text { God send me } \\
\text { sorrow. }\end{array}$ & $\begin{array}{l}\text { Sollte ich damit } \\
\text { geizen, möge Gott } \\
\text { mir Kummer } \\
\text { bereiten. }\end{array}$ & $\begin{array}{l}\text { Bin ich gefügig } \\
\text { nicht, geb Gott } \\
\text { mir Sorgen. }\end{array}$ \\
\hline
\end{tabular}

The second example from Chaucer's Wife of Bath'sPrologue is concerned with a different structural level, this time, the five sentences all look completely alike apart from the translation of one word. Again, this could be seen simply as a question of the linguistic discipline of lexicology, not of pragmatics. Clearly, the word in question, dangerous, has changed in meaning from 1450 to today, therefore none of the two English translations use the etymologically closest equivalent in modern English. The Middle English glossary (Chaucer Riverside Edition glossary) lists the following meanings:

1. domineering, disdainful

2. disdainful, standoffish, unaccommodating

3. niggardly, grudging (the latter is the suggested meaning for this passage in the Chaucer Riverside Edition glossary) 
But of the many meanings of dangerous offered in the Middle English glossary Coghill and Lehnert come up with a translation that seems removed from the context. The translations as difficult and nicht gefügig (which means 'not obedient') suggest meaning 1, "domineering" rather than 3, "grudging". Again, we are presented with two very different interpretations of the meaning of this passage. We see Coghill's and Lehnert's versions as separate from the context, as the question of obedience was not discussed. This is the end of a passage in which the Wife of Bath discusses the merits of being either chaste or a wife and is trying to favour the virtues of wifehood and active sexuality versus holiness and chastity, at least aiming at giving them an equal status - again a question of gaining status and respect. Again, the same two translators, Lumianksy and Kemmler go for the version "I will fulfil my status", interpreting dangerous as "not fulfilling marital duties", while Coghill's and Lehnert's versions ("If I should not be obedient ...") create a meaning of self-reproach, which is not relevant to the context, but probably relevant to the overall frame evoked by these two translators, that of a lamenting woman, reproaching both herself and her husband for the woe in marriage. That a different cultural concept may be to blame here more than a misunderstanding of this word is further supported by the fact that there is a passage in the Chaucer text (III, 514) where all four translators translated dangerous with the meaning chosen by Lumiansky and Kemmler here, "standoffish, noncompliant", rather than "domineering", but in this case the adjective applies to the husband's duties.

As was demonstrated in the examples from the Cantar de mio Cid, the fact that the translator took a certain decision indicates that some changes in general interactional behaviour are perceived. This particular passage also points at the problem of greater explicitness of the translation: The translator does not really produce the same illocution, he produces the same illocution but in a more forceful manner. Lumiansky and Kemmler, while in our view closer to the interpretation of the original, still had to make their illocution more forceful, losing the multiplicity of meanings and having to opt for one specific, sexual interpretation of dangerous here. But Coghill and Lehnert are equally explicit, though in our view focusing on an illocution not relevant to the original author. However, the general statement that translations by nature have to be more explicit than originals (Blum-Kulka 1986:9) is only relevant if we assume that the illocution of the translated text could ideally correspond exactly to that of the original, yet it is only through the translation variants that we find out about the possible range of illocutions contained in the original (Frank 1988). It is the task of historical pragmatics to then point out which one best fits the general cultural values of the time.

\section{Conclusion}

In our paper we have tried to sketch a framework that could serve as a basis for combined approaches in historical pragmatics and translation studies. As has been shown, both historical pragmatics and translation studies can use each other as indicators for their research. For historical pragmatics, translation comparison on the pragmatic level constitutes valuable material for tracing changes in speech acts and speech act patterns. On the other hand, the historicity of speech acts which is at the very centre of historical pragmatics can help translation studies to determine the particular challenges and problems that are faced by the translator when translating historically determined texts into the modern idiom and the modern frame of speech acts. This is especially true for translation scholars who deal with historical texts of a by-gone culture and who are often torn between the necessities of pragmatic remodelling and the wish to retain the alterity of the text - be it out of philological traditions or out of respect for a text considered as a poetic masterpiece.

Through our text analyses and their theoretical frame we hope to have shown that the co-operation between an inherently contrastive historical approach in pragmatics and translation studies can be rewarding and stimulating for both disciplines. For historical pragmatics the method of translation comparison not only 
provides useful theoretical and methodological insights but also valuable text material for studies on the evolution of speech acts and their traditions through time. When analysing historical texts like the Cantar de mio Cid or the Wife of Bath's Prologue and Tale, one could e.g. analyse how a specific speech act pattern was translated not only in the 20th century but through a much longer period of time - however, this is a chapter in translation studies and historical pragmatics that we will not open in this paper.

\section{References}

Primary texts

Cantar de mio Cid. (1993). Edición, prólogo y notas de Alberto Montaner. 2. edición corregida. Crítica, Barcelona.

Translations

Poema de mio Cid. (1926). Puesto en romance vulgar y lenguaje moderno por Pedro Salinas. Revista de Occidente, Madrid.

Cantar de mio Cid. (1997). Edición de Francisco Marcos Marín. Editorial Biblioteca Nueva, Madrid.

The Poem of the Cid. (1975). A Bilingual Edition with Parallel Text. Translated by Rita Hamilton and Janet Perry with an Introduction and Notes by Ian Michael. Penguin, London.

The Poem of My Cid. (1991). Translated with an Introduction \& Commentary by Peter Such \& John Hodgkinson. Second corrected impression. Aris \& Phillips, Warminster.

The Riverside Chaucer. (1988). General editor: Larry D. Benson. Oxford University Press, Oxford.

Translations

Chaucer, Geoffrey: The Canterbury Tales. (1977). Translated into modern English by Nevill Coghill. Penguin, London.

Chaucer, Geoffrey: The Canterbury Tales. (1977). A new modern English prose translation by R. M. Lumiansky. Pocket Books, New York.

Chaucer, Geoffrey: Canterbury-Erzählungen. (1989). In deutsche Prosa übertragen von Fritz Kemmler. Goldmann, München.

Chaucer, Geoffrey: Canterbury-Erzählungen. (1963). Herausgegeben und übersetzt von Martin Lehnert. Ausstattung u. Illustrationen: Werner Klemke. Rütten \& Loening, Berlin.

\section{Works cited}

Albrecht, J. (1973). Linguistik und Übersetzung. Niemeyer, Tübingen.

Arnovick, L. K. (2000). Diachronic Pragmatics. Seven Case Studies in English Illocutionary Development. John Benjamins, Amsterdam/Philadelphia.

Blum-Kulka, S. (1986): Shifts of Cohesion and Coherence in Translation. In: Interlingual and Intercultural Communication (J. House and S. Blum-Kulka, eds.), pp. 7-35. Narr, Tübingen. 
Blum-Kulka, S., and J. House (1989). Investigating Cross-Cultural Pragmatics: An Introductory Overview. In: Cross-Cultural Pragmatics: Requests and Apologies. (S. Blum-Kulka, J. House and G. Kasper, eds.), pp. 1-34. Ablex, Norwood.

Bucher, H. J. (1994). Frage-Antwort-Dialoge. In: Handbuch der Dialoganalyse. (G. Fritz and F. Hundsnurscher, eds.), pp. 239-258. Niemeyer, Tübingen.

Catford, J.C. (1965). A Linguistic Theory of Translation. OUP, London.

Cerquiglini, B. (1981). La parole médiévale. Minuit, Paris.

Cherubim, D. (1980). Zum Programm der historischen Sprachpragmatik. In: Ansätze zu einer pragmatischen Sprachgeschichte. (H. Sitta, ed.), pp. 3-21. Niemeyer, Tübingen.

Doherty, M. (1990). Focus Hierarchies. Acta Linguistica Hungarica 40, 275-284.

Diller, H. J. and J. Kornelius (1978). Linguistische Probleme der Übersetzung. Niemeyer, Tübingen.

Eberenz, R. (1991). Castellano antiguo y español moderno: Reflexiones sobre la periodización en la historia de la lengua. Revista de Filología española 71, 79-106.

Ehlich, K. (1992). On the historicity of politeness. In: Politeness in Language. Studies in its History, Theory and Practice. (R. Watts, S. Ide and K. Ehlich, eds.), pp. 71-107. Mouton de Gruyter, Berlin/New York.

Frank, A. P. (1988). Understanding Literature via translation: The translation as hermeneutic device. Literatur in Wissenschaft und Unterricht, 21-1, 33-37.

Fritz, G. (1995). Topics in the History of Dialogue Forms. In: Historical Pragmatics. Pragmatic Developments in the History of English. (A. H. Jucker, ed.), pp. 469-498. John Benjamins, Amsterdam/Philadelphia.

Fritz, G. (1997). Remarks on the History of Dialogue Forms. In: Dialoganalyse V. Referate der 5. Arbeitstagung Paris 1994. (E. Petri, D. Laroche-Bouvy and S. Stati, eds.), pp. 47-55. Niemeyer, Tübingen.

Grosse, S. (1986). Überblick über die Rezeption der deutschen Literatur des Mittelalters im 19. Jahrhundert. In: Mittelalter-Rezeption. Ein Symposion. (Peter Wapnewski, ed.), pp. 377-391. Metzlersche Verlagsbuchhandlung, Stuttgart.

Hawkins, J. (1986). A Comparative Typology of English and German. Croom Helm, London \& Sydney.

Hönig, H. G. and P. Kussmaul. (1982). Strategien der Übersetzung. Ein Lehr- und Arbeitsbuch. Narr, Tübingen.

Hönig, H. G. (1995). Wieviel Sprechakttheorie braucht ein Dolmetscher? In: Sprachtransfer Kulturtransfer (N. Salnikow, ed.), pp. 23-30. Peter Lang, Frankfurt a. M.

House, J. (1997). Translation Quality Assessment - A Model Revisited. Narr, Tübingen.

Jauß, H. R. (1977). Alterität und Modernität in der mittelalterlichen Literatur. Gesammelte Aufsätze 19551976. Fink, München.

Jucker, A. H. and A. Jacobs. (1995). The Historical Perspective in Pragmatics. In: Historical Pragmatics. Pragmatic Developments in the History of English. (A. H. Jucker, ed.), pp. 3-33. John Benjamins, Amsterdam/Philadelphia. 
Jucker, A. H. and I. Taavitsainen. (2000). Diachronic speech act analysis. Insults from flyting to flaming. Journal of Historical Pragmatics 1, 67-95.

Jucker, A. H., G. Fritz and F. Lebsanft (eds.). 1999. Historical Dialogue Analysis. John Benjamins, Amsterdam/Philadelphia.

Jung, V. (1999) English-German Self-Translation and its Relevance for Translation Theory and Practice. [ $\mathrm{Ph}$. D. thesis, University of Düsseldorf].

Kerbrat-Orecchioni, C. (1991). Introduction. In: La question. (C. Kerbrat-Oreccioni, ed.), pp. 5-37. Presses universitaires, Lyon.

Kussmaul, P. (1980). Sprechakttheorie. Ein Reader. Athenaion, Wiesbaden.

Kussmaul, P. (1995). Zur Relevanz einiger Semantikmodelle für die Übersetzung. In: Sprachtransfer Kulturtransfer (N. Salnikow, ed.), pp. 31-47. Peter Lang, Frankfurt a. M.

Lebsanft, F. (1988). Studien zu einer Linguistik des Grußes. Sprache und Funktion der altfranzösischen Grußformeln. Niemeyer, Tübingen.

Lebsanft, F. (1999). A Late Medieval Bargain Dialogue ('Pathelin' II). Or: Further Remarks on the History of Dialogue Forms. In: Historical Dialogue Analysis. (A. H. Jucker, G. Fritz and F. Lebsanft, eds.), pp. 269-292. John Benjamins, Amsterdam/Philadelphia.

Liedtke, F. (1998). Grammatik der Illokution. Über Sprechhandlungen und ihre Realisierungsformen im Deutschen. Narr, Tübingen.

López Estrada, F. (21961). Prólogo. In: Poema del Cid. (F. López Estrada, ed.), pp. XI-LXVIII. Castalia: Madrid.

Meibauer, J. (1986). Rhetorische Fragen. Niemeyer, Tübingen.

Nord, C. (1997). Translation as a Purposeful Activity - Functional Approaches Explained. St. Jerome, Manchester.

Reiss, K. (21982). Texttyp und Übersetzungsmethode - Der operative Text. Gross, Heidelberg.

Reiss, K., and H. Vermeer. (1984). Grundlegung einer allgemeinen Translationstheorie. Niemeyer, Tübingen.

Rodiek, C. (1990). Sujet - Kontext - Gattung. Die internationale Cid-Rezeption. Walter de Gruyter, Berlin/New York.

Salinas, P. (1961 [1945]). El "Cantar de mio Cid". Poema de la honra. In: Pedro Salinas - Ensayos de literatura española. Del 'Cantar de mio Cid' a García Lorca. (J. Marichal, ed.), pp. 27-43. Aguilar, Madrid.

Schlieben-Lange, B. (1983). Traditionen des Sprechens. Elemente einer pragmatischen Sprachgeschichtsschreibung. Kohlhammer, Stuttgart/Berlin etc.

Schlieben-Lange, B. and H. Weydt (mit Beiträgen von E. Coseriu und H. U. Gumbrecht) (1979): Streitgespräch zur Historizität von Sprechakten. Linguistische Berichte 60, 65-78.

Schrott, A. (1999). Que fais, Adam? Questions and Seduction in the 'Jeu d'Adam'. In: Historical Dialogue Analysis. (A. H. Jucker, G. Fritz and F. Lebsanft, eds.), pp. 331-370. John Benjamins, Amsterdam/Philadelphia. 
Schrott, A. (2000). ¿Quí los podrié contar? Interrogative Acts in the 'Cantar de mio Cid'. Some Examples from Old Spanish on Asking Questions. Journal of Historical Pragmatics 1, 263-300.

Sacks, H., E. A. Schegloff and G. Jefferson. (1974). A Simplest Systematics for the Organisation of TurnTaking for Conversation. Language 50, 696-735.

Searle, J. R. (1969). Speech Acts. An Essay in the Philosophy of Language. Cambridge University Press, Cambridge.

Searle, J. R. (1979). Expression and Meaning. Studies in the Theory of Speech Acts. Cambridge University Press, Cambridge.

Stein, D. (1985). Perspectives on Historical pragmatics. Papers from the Workshop on Socio-Historical Linguistics. Folia Linguistica Historica 6, 347-352.

Walsh, J. K. (1990). Performance in the 'Poema de mio Cid'. Romance Philology 44, 1-25.

Wierzbicka, A. (1991). Cross-Cultural Pragmatics. The Semantics of Human Interaction. Mouton de Gruyter, Berlin/New York.

Wilss, W. (1982). The Science of Translation: Problems and Methods. Narr, Tübingen.

Wilss, W.(1996): Übersetzungsunterricht. Narr, Tübingen.

Wolfson, N. (1989). Problems in the Comparison of Speech Acts Across Cultures. In: Cross-Cultural Pragmatics: Requests and Apologies (S. Blum-Kulka, J. House and G. Kasper, eds.), pp. 174-196. Ablex, Norwood. 